\title{
SYNTHESIS AND SPECTROSCOPIC CHARACTERIZATION OF SOME NEW HYDROGENOXALATO ORGANOTIN (IV) COMPLEXES
}

\author{
MOUHAMADOU SEMBENE BOYE ${ }^{1 *}$, AMINATA DIASSE-SARR ${ }^{2}$, LIBASSE $^{2}$ \\ DIOP $^{2}$ \\ ${ }^{1}$ University Cheikh Anta Diop, Faculty of Sciences and Technologies of Education and \\ Training, Department of Physics Chemistry, Boulevard Habib Bourguiba, 5036 Fann- \\ Dakar, Senegal \\ ${ }^{2}$ Senegal Cheikh Anta Diop University, Faculty of Science and Technology, Department of \\ Chemistry, Laboratory of Mineral and Analytical Chemistry, Dakar, Senegal.
}

\begin{abstract}
The synthesis and spectroscopic studies (infrared and Mössbauer) of new hydrogenoxalato derivatives and adducts containing $\mathrm{SnR}_{\mathrm{n}}(\mathrm{R}=\mathrm{Me}, \mathrm{Ph} ; \mathrm{n}=2,3)$ residues are reported. Based on their spectroscopic data dimeric and polymeric structures containing hexacoordinated or pentacoordinated $\mathrm{Sn}$ are suggested ${ }_{2}$ the hydrogenoxolate anion behaving as a monocoordinating or a monochelating ligand. In two studied adducts, supramolecular architectures may be obtained when extra hydrogen bonds involving the free NH groups are considered.
\end{abstract}

Keywords: dimeric and polymeric structures, hydrogenoxalate, monochelating, monocoordinating, octahedral or trigonal bipyramidal environments, spectroscopy, supramolecular architectures.

\section{INTRODUCTION}

Several papers on oxalato and hydrogenoxalato complexes have been reported [1-6], while only few hydrogenoxalato tin ones are known [7]. In this work we have synthesized four new hydrogenoxalato derivatives and adducts containing $\mathrm{SnR}_{\mathrm{n}}(\mathrm{R}=\mathrm{Me}, \mathrm{Ph}$ and $\mathrm{n}=2,3)$ residues using the $\mathrm{H}_{3} \mathrm{~N}\left(\mathrm{CH}_{2}\right)_{2} \mathrm{NH}_{3}\left(\mathrm{HC}_{2} \mathrm{O}_{4}\right)_{2} \cdot \mathrm{H}_{2} \mathrm{O}$ salt while the adduct $\mathrm{C}_{4} \mathrm{~N}_{2} \mathrm{H}_{12}\left(\mathrm{HC}_{2} \mathrm{O}_{4}\right)_{2} \cdot 2 \mathrm{SnPh}_{2} \mathrm{Cl}_{2}$ is obtained by reacting in situ piperazine $\left[\mathrm{NH}\left(\mathrm{C}_{4} \mathrm{H}_{8}\right) \mathrm{NH}\right]$ with $\mathrm{H}_{2} \mathrm{C}_{2} \mathrm{O}_{4}$ and $\mathrm{SnPh}_{2} \mathrm{Cl}_{2}$. These compounds have been studied by infrared and Mössbauer spectroscopies and structures proposed based on spectroscopic data.

\section{EXPERIMENTAL SETUP}

\subsection{Salt synthesis}

$\mathrm{H}_{3} \mathrm{~N}\left(\mathrm{CH}_{2}\right)_{2} \mathrm{NH}_{3}\left(\mathrm{HC}_{2} \mathrm{O}_{4}\right)_{2} \mathrm{H}_{2} \mathrm{O}(\mathbf{L})$ was obtained as white powder by partial neutralization of the $\mathrm{H}_{2} \mathrm{C}_{2} \mathrm{O}_{4}$ acid by $\mathrm{H}_{2} \mathrm{~N}\left(\mathrm{CH}_{2}\right)_{2} \mathrm{NH}_{2}(98 \%)$ in 1:1 ratio as reported by Barnes et al. [8] and Vaidhyanathan et al. [9].

\footnotetext{
${ }^{*}$ Corresponding author, email: mouhasboye@ hotmail.com

(C) 2020 Alma Mater Publishing House
} 


\subsection{Compounds synthesis}

The studied compounds (A, B, C, D) were obtained as white precipitates.

-(A): by mixing $\mathbf{L}(1.32 \mathrm{mmol})$ in water with $\mathrm{SnMe}_{2} \mathrm{Cl}_{2}(1.32 \mathrm{mmol})$ in ethanol in 1:1 ratio. m.p. $>260{ }^{\circ} \mathrm{C}$.

- (B): by mixing $\mathbf{L}(1.85 \mathrm{mmol})$ in water with $\mathrm{SnPh}_{2} \mathrm{Cl}_{2}(1.85 \mathrm{mmol})$ in ethanol in 1:1 ratio. m.p. $>260{ }^{\circ} \mathrm{C}$.

$-(\mathbf{C})$ : by mixing $\mathbf{L}(2.00 \mathrm{mmol})$ in water with $\mathrm{SnMe}_{3} \mathrm{Cl}(2.00 \mathrm{mmol})$ in dichloromethane in $1: 1$ ratio. m.p. $=236{ }^{\circ} \mathrm{C}$.

- (D): by mixing piperazine $\left[\mathrm{NH}\left(\mathrm{C}_{4} \mathrm{H}_{8}\right) \mathrm{NH}\right](1.14 \mathrm{mmol})$ in water with $\mathrm{H}_{2} \mathrm{C}_{2} \mathrm{O}_{4}(2.48 \mathrm{mmol})$ in water and $\mathrm{SnPh}_{2} \mathrm{Cl}_{2}$ (1.14 mmol) in ethanol in 1:2:1 ratio. m.p. $>260{ }^{\circ} \mathrm{C}$.

All the precipitates were stirred around two hours before being filtered.

The analytical data reported in Table 1, have allowed to suggest the following formulae:
$\mathrm{A}: \mathrm{SnMe}_{2}\left(\mathrm{HC}_{2} \mathrm{O}_{4}\right)_{2}$
$\mathrm{B}: \mathrm{SnPh}_{2}\left(\mathrm{HC}_{2} \mathrm{O}_{4}\right)_{2}$
$\mathrm{C}:\left[\mathrm{H}_{3} \mathrm{~N}\left(\mathrm{CH}_{2}\right)_{2} \mathrm{NH}_{3}\left(\mathrm{HC}_{2} \mathrm{O}_{4}\right)_{2}\right] \cdot 2 \mathrm{SnMe} 3 \mathrm{Cl}$
D: $\mathrm{C}_{4} \mathrm{~N}_{2} \mathrm{H}_{12}\left(\mathrm{HC}_{2} \mathrm{O}_{4}\right)_{2} \cdot 2 \mathrm{SnPh}_{2} \mathrm{Cl}_{2}$

Table 1. Analytical data of compounds A-D.

\begin{tabular}{|c|c|c|c|c|c|c|}
\hline \multirow{3}{*}{ Compound } & \multicolumn{6}{|c|}{ Chemical composition [\% mass] } \\
\hline & \multicolumn{2}{|c|}{$\mathbf{C}$} & \multicolumn{2}{|c|}{$\mathbf{H}$} & \multicolumn{2}{|c|}{$\mathbf{N}$} \\
\hline & Calc. & Found & Calc. & Found & Calc. & Found \\
\hline $\mathbf{L}$ & 28.36 & 28.59 & 4.72 & 4.43 & 11.02 & 11.20 \\
\hline $\mathbf{A}$ & 22.05 & 21.99 & 2.46 & 2.43 & - & - \\
\hline B & 40.98 & 41.02 & 3.01 & 3.04 & - & - \\
\hline $\mathbf{C}$ & 22.57 & 22.60 & 4.73 & 4.66 & 4.39 & 4.36 \\
\hline D & 40.29 & 40.35 & 3.59 & 3.65 & 2.94 & 2.98 \\
\hline
\end{tabular}

Elemental analyses have been obtained at the ICMCB-Bordeaux University (France) with a CHNS: Flash EA 1112 Thermofisher. Infrared spectra have been recorded at the CRPP-Bordeaux University (France) using a Nicolet 6700 FT-IR spectrophotometer on diamond. Mössbauer spectra were recorded at the ICMCB-Bordeaux (France) on a liquid helium cryostat with a HALDER spectrometer.

Infrared abbreviations: br (broad); sh (shoulder) vs (very strong); s (strong); m (medium); w (weak). Mössbauer abbreviations: $\Delta$ (quadrupole splitting); $\delta$ (isomer shift); $\Gamma$ (full width at half-height). The chemicals were purchased from Aldrich Company-Germany without any further purification.

\section{RESULTS AND DISCUSSION}

\section{Spectroscopic study}

Let us consider the main IR data (in $\mathrm{cm}^{-1}$ ) of the compounds $\mathbf{A}-\mathbf{D}$ :

A: $v \mathrm{CO}_{2}{ }^{-} 1699(\mathrm{~s}), 1628(\mathrm{~s}), 1350(\mathrm{~s}), \operatorname{vasSnMe} 2$ 585(m), vSnO 239(s);

B: $v_{C_{2}}^{-1} 1620(\mathrm{sh}), 1607(\mathrm{vs}), 1352(\mathrm{~m}), \mathrm{vasSnPh}_{2}$ 284(m), vSnO 206(m);

C: $v \mathrm{OH}+v_{\mathrm{NH}_{3}}{ }^{+}$3386(br), $\mathrm{vCO}_{2}^{-}$1635(vs), 1283(vs), 1224(s), vsSnMe 3 523(w), vasSnMe $\mathrm{S}_{3}$ 561(w), vSnO 240(vs);

D: $v \mathrm{OH}+\mathrm{vNH}_{3}{ }^{+}$3277(br), $v \mathrm{CO}_{2}{ }^{-}$1569(sh), 1481(m), 1351(m), vPh 729(vs), 690(vs).

and their Mössbauer data $\left(\mathrm{mm}^{-1}\right)$ of $\mathbf{A}$ and $\mathbf{B}$ :

A: $\Delta=4.46 ; \delta=1.52 ; \Gamma=1.08$;

B: $\Delta=4.52 ; \delta=1.33 ; \Gamma=0.92$.

For $\mathbf{A}$ and $\mathbf{B}$, the absence of a band assigned to $\mathrm{vsSnC}_{2}$ on the infrared spectra of these two derivatives allows to conclude to linear $\mathrm{SnMe}_{2}$ and $\mathrm{SnPh}_{2}$ groups. The vasSnC 2 vibration is located respectively at $585 \mathrm{~cm}^{-1}$ and at 284 $\mathrm{cm}^{-1}$ on the infrared spectra. The broad absorptions around $3300 \mathrm{~cm}^{-1}$ on the infrared spectra of these two compounds attributed to $\mathrm{vOH}$ indicate the existence of hydrogen bonds. 
The value of the quadrupole splitting of (A) $\left(\Delta=4.52 \mathrm{~mm}^{-1}\right)$ is greater than that of $\mathrm{SnMe}_{2} \mathrm{Cl}_{2}\left(\Delta=3.56 \mathrm{~mm} \cdot \mathrm{s}^{-1}\right)$ [10] in which the $\mathrm{SnMe}_{2}$ group is dissymmetrically transcoordinated with an octahedral environment around tin atom (in $\mathrm{Me}_{2} \mathrm{Sn}\left(\mathrm{O}_{2} \mathrm{PPh}_{2}\right)_{2}$ which contains a tin center in a trans octahedrally coordinated environment $(\Delta=4.45$ $\left.\left.\mathrm{mm} \cdot \mathrm{s}^{-1}\right)\right)[11]$.

The value of the quadrupole splitting of $(\mathbf{B})\left(\Delta=4.45 \mathrm{~mm}^{-1}\right)$ greater than the one of $\mathrm{SnPh}_{2} \mathrm{Cl}_{2}\left(\Delta=2.89 \mathrm{~mm} \cdot \mathrm{s}^{-1}\right)$ [12] is in agreement with a transcoordinated $\mathrm{SnPh}_{2}$ group and a trans octahedral environment around tin atom [13]. The structure resulting from these spectroscopic data is an infinite chain structure with a transcoordination of the $\mathrm{SnR}_{2}$ group, an octahedral environment around tin center and a chelating hydrogenoxalate anion (Figure $1)$.

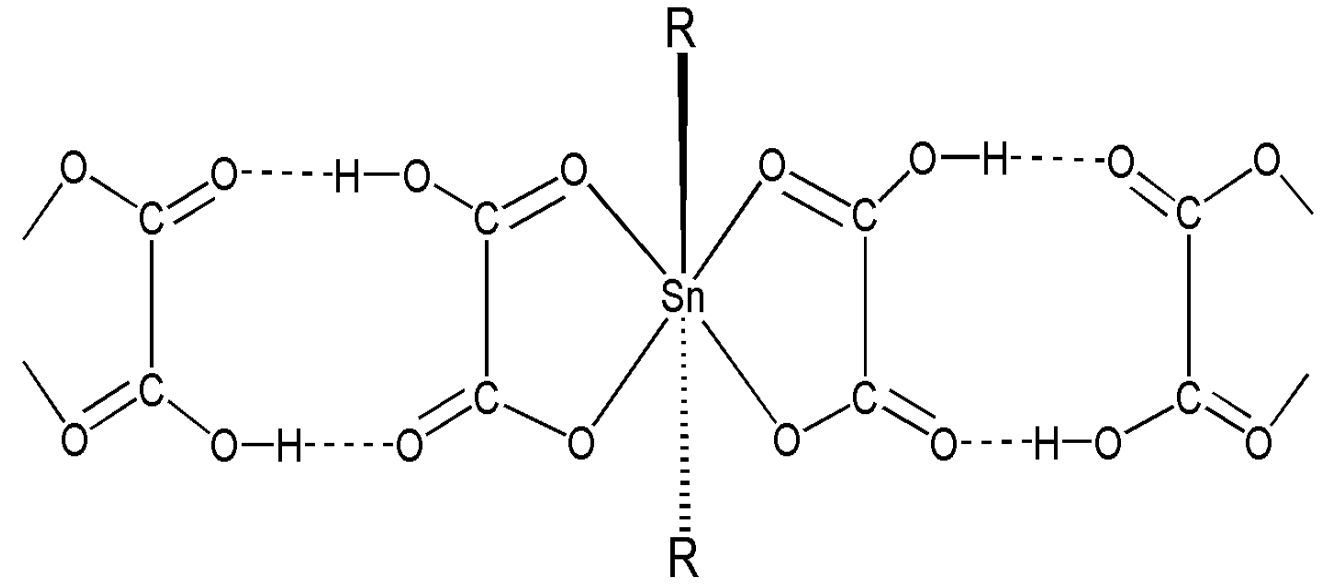

Fig. 1. Proposed structure for compounds $\mathbf{A}$ and $\mathbf{B}(\mathbf{R}=\mathbf{M e}, \mathbf{P h})$.

For $\mathbf{C}$, the vibration $v \mathrm{SSnMe}_{3}$ appears at $523 \mathrm{~cm}^{-1}$ and indicates a non-planar $\mathrm{SnMe}_{3}$ group. The vasSnMe vibration is localized at $550 \mathrm{~cm}^{-1}$. The band at $240 \mathrm{~cm}^{-1}$ attributed to $v \mathrm{SnO}$ indicates the metal-ligand bond.

Based on the spectroscopic data we propose for this compound a dimeric structure with a unidentate anion and a trigonal bipyramidal environment around the tin atom. The monomer of this dimer can be considered as two anions $\left[\mathrm{HC}_{2} \mathrm{O}_{4} \mathrm{SnMe}_{3} \mathrm{Cl}\right]^{-}$linked by $\mathrm{NH}$... $\mathrm{O}$ type hydrogen bonds via the ethylenediammonium ion $\left[{ }^{+} \mathrm{H}_{3} \mathrm{~N}\left(\mathrm{CH}_{2}\right)_{2} \mathrm{NH}_{3}{ }^{+}\right]$(Figure 2).

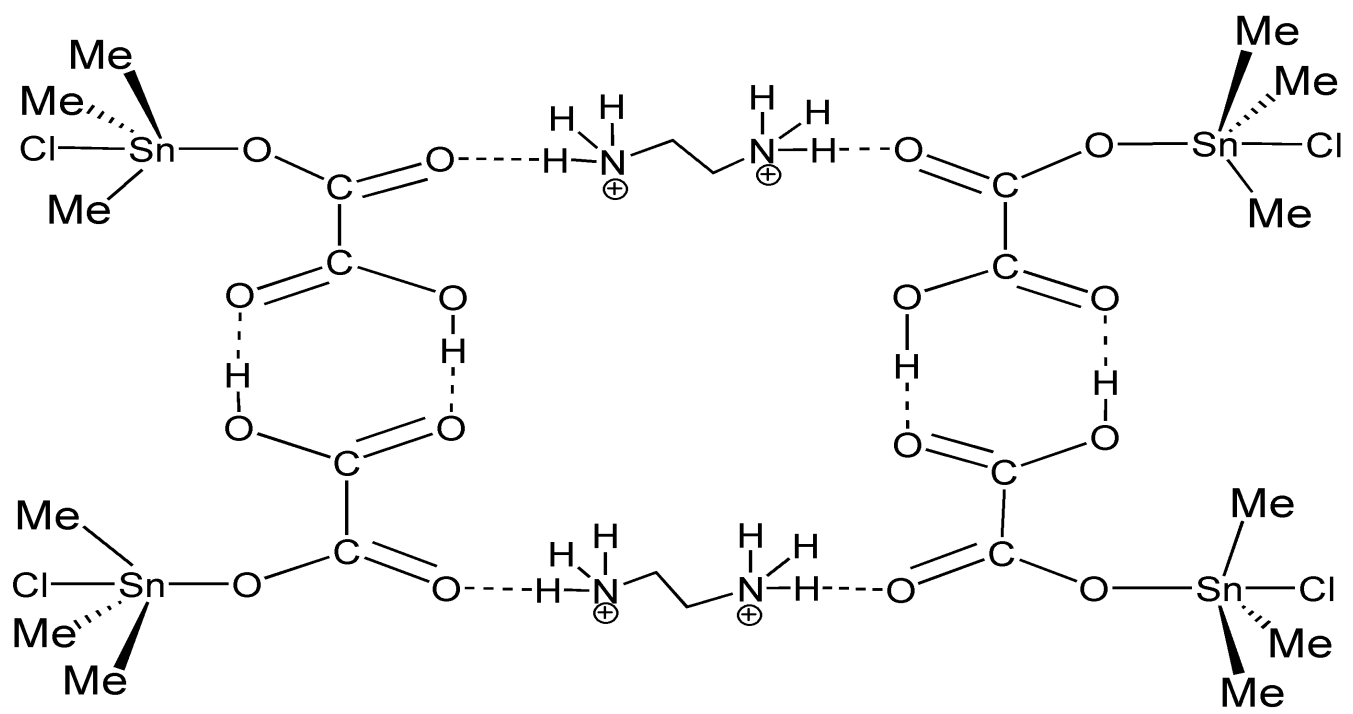

Fig. 2. Proposed structure for the compound (C).

For $\mathbf{D}$, the broad absorption at $3277 \mathrm{~cm}^{-1}$ on the infrared spectrum attributed to $\mathrm{vOH}$ of the hydroxyl group of the oxyanion indicates the existence of hydrogen bonds. 
Based on the spectroscopic data we propose for this compound a dimeric structure containing octahedral tin centres with a monochelating anion and transcoordinated $\mathrm{SnPh}_{2}$ residues. By analogy with the complex (C), this complex can be considered as two anions $\left[\mathrm{HC}_{2} \mathrm{O}_{4} \mathrm{SnPh}_{2} \mathrm{Cl}_{2}\right]^{-}$connected by $\mathrm{NH}$...O hydrogen bonds via $\left[{ }^{+} \mathrm{H}_{2} \mathrm{~N}\left(\mathrm{C}_{4} \mathrm{H}_{8}\right) \mathrm{NH}_{2}^{+}\right]$and a dimerization through acetic acid hydrogen bonds types (Figure 3).

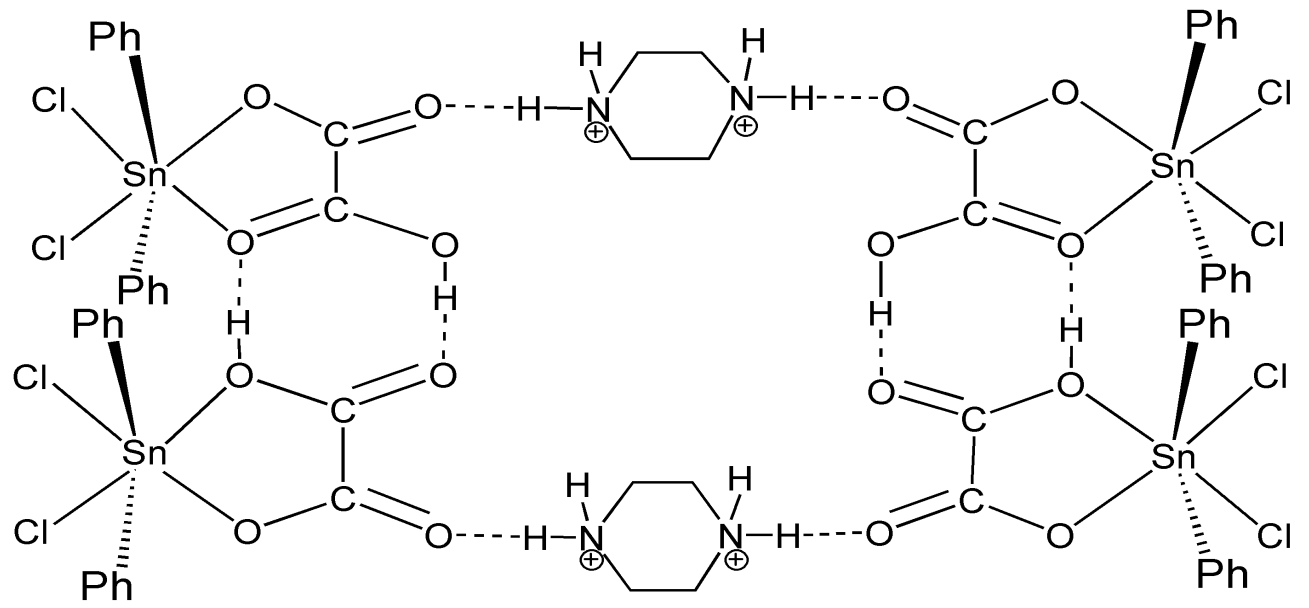

Fig. 3. Proposed structure for the compound (D).

In (C) and (D) the free $\mathrm{NH}$ groups may be considered involved in extra hydrogen bonds leading to supramolecular architectures.

\section{CONCLUSIONS}

The studied compounds have dimeric and infinite chain structures, the environment around the tin atoms being octahedral or trigonal bipyramidal, the hydrogenoxalate anion behaving as a monocoordinating or monochelating ligand. The use of diamines has allowed us to isolate two adducts containing dications $\mathrm{H}_{3} \mathrm{~N}\left(\mathrm{CH}_{2}\right)_{2} \mathrm{NH}_{3}\left(\mathrm{HC}_{2} \mathrm{O}_{4}\right)_{2} \cdot 2 \mathrm{SnMe}_{3} \mathrm{Cl}$ and $\mathrm{C}_{4} \mathrm{~N}_{2} \mathrm{H}_{12}\left(\mathrm{HC}_{2} \mathrm{O}_{4}\right)_{2} \cdot 2 \mathrm{SnPh}_{2} \mathrm{Cl}_{2}$ whose proposed structures contain hydrogen bonds between the cations and the oxyanions (in these two last adducts, considering extra hydrogen bonds involving the free $\mathrm{NH}$ groups may lead to supramolecular architectures).

\section{ACKNOWLEDGEMENTS}

We thank Mr. Patrick Rosa, Mr. Alain Wattiaux (ICMBC-Bordeaux University, France) and the CRPPBordeaux University for equipment support.

\section{REFERENCES}

[1] Chen, X.F., Liu, L., Ma, J.G., Yi, L., Cheng, P., Liao, D.Z., Yan, S.P., Jiang, Z.H., Synthesis, reaction and structure of a series of chromium(III) complexes containing oxalate ligand, Journal of Molecular Structure, vol. 750 , no. $1-3,2005$, p. $94-100$.

[2] Yang, X., Li, J., Zhao, X.H., Wang, H.W., Shan, Y.K., Hydrogen bonding and $\pi-\pi$ stacking in the three-dimensional supra-molecular complex bis-(4,4'-bipyridinium) diaqua-dioxalatoferrate(II) bis(hydrogen oxalate), Acta Crystallographica Section C: Structural Chemistry, vol. 63, part 4, 2007, p. m171-m173.

[3] Yeşilel, O.Z., Erer, H., Odabaşoğlu, M., Büyükgüngör, O., A novel copper (II)-hydrogen oxalate coordination polymer showing a new coordination mode, Journal of Inorganic and Organometallic Polymers and Materials, vol. 20, no. 1, 2010, p. 78-82.

[4] Androš, L., Jurić, M., Molčanov, K., Planinić, P., Supramolecular architectures of novel chromium (III) oxalate complexes: steric effects of the ligand size and building-blocks approach, Dalton Transactions, vol. 41, no. 48,2012 , p. 14611-14624. 
[5] Piro, O.E., Echeverria, G.A., González-Baró, A.C., Baran, E.J., $\mathrm{Tl}_{2} \mathrm{C}_{2} \mathrm{O}_{4} \cdot \mathrm{H}_{2} \mathrm{C}_{2} \mathrm{O}_{4}$ : a new crystalline form of thallium(I) oxalate, Zeitschrift für Naturforschung B, A Journal of Chemical Sciences, vol. 70, no. 4, 2015 , p. 249-252.

[6] Sarr, B., Diop, C.A.K., Sidibe, M., Rousselin, Y., Crystal structure of bis(diisopropylammonium) cis-diiodidobis(oxolato- $\kappa^{2} \mathrm{O}^{1}, \mathrm{O}^{2}$ ) stannate(IV), Acta Crystallographica Section E: Crystallographic Communications, vol. 74, part 4, 2018, p. 502-504.

[7] Boye, M.S., Diasse-Sarr A., Synthèse et caracterisation par spectroscopies infrarouge et Mössbauer de nouveaux derives glutarato, 3,3-dimethylglutarato et hydrogenooxalato contenant le residu $\mathrm{SnR}_{2}[\mathrm{R}=\mathrm{Me}, \mathrm{Bu}]$, Comptes Rendus Chimie, vol. 10, no. 6, 2007, p. 489-492.

[8] Barnes, J.C., Longhurst, R.W., Weakley, T.J.R., Ethylenediammonium bis (monohydrogen oxalate) monohydrate and two modifications of trimethylenediammonium bis (monohydrogen oxalate) monohydrate, Acta Crystallographica Section C: Structural Chemistry, vol. 54, part 9, 1998, p. 1347-1351.

[9] Vaidhyanathan, R., Natarajan, S., Rao, C.R., Hydrogen bonded structures in organic amine oxalates, Journal of Molecular Structure, vol. 608, no. 2-3, 2002, p. 123-133.

[10] Parish, R.V., Platt, R.H., Studies in Mössbauer spectroscopy. Part II. The structures of some organotin halides, and a test of the point-charge mode, Inorganica Chemica Acta, vol. 4, 1970, p. 65-72.

[11] Sidibe, M., Lahlou, M., Diop, L., Mahieu, B., $\mathrm{R}_{2} \mathrm{SnA}_{2}, \mathrm{R}_{2} \mathrm{Sn}(\mathrm{Cl}) \mathrm{A}, \mathrm{Me}_{3} \mathrm{Sn}\left(\mathrm{O}_{2} \mathrm{PPh}_{2}\right)(\mathrm{R}=\mathrm{Me}, \mathrm{Bu}$; $\mathrm{A}=\mathrm{Me}_{2} \mathrm{AsO}_{2}, \mathrm{Ph}_{2} \mathrm{PO}_{2}$ ): synthesis, IR, Raman, Mössbauer and NMR studies, Main Group Metal Chemistry, 1998, vol. 21, no. 10, 1998, p. 605-608.

[12] Davies, A.G., Smith, P.J., Tin, Comprehensive organometallic chemistry (Editors: Wilkinson, G., Stone, F. G.A, Abel, E.W) Pergamon Press, Oxford, vol. 2, no. 26, 1982, p. 519.

[13] Barbieri, R., Huber, F., Pellerito, L., Ruisi, G., Silvestri, A., ${ }^{119}$ Sn Mössbauer Studies on Tin compounds, chemistry of tin, (Editor: Smith, P.J.), Blackie, London, chapter 14, 1998, p. 496-540. 